\title{
Unrelenting burden of anaemia in India: Highlighting possible prevention strategies
}

\author{
Ravi Prakash Upadhyay ${ }^{1}$, Palanivel $C^{2}$ and Vaman Kulkarni ${ }^{3}$ \\ ${ }^{1} M B B S, M D$; Centre for Community Medicine, All India Institute of Medical Sciences, New Delhi, India \\ ${ }^{2}$ MBBS, MD, Assistant Professor, Department of Community Medicine, Indira Gandhi Medical College and Research Institute, \\ Puducherry, India \\ ${ }^{3}$ MBBS, MD. Assistant Professor, Department of Community Medicine, Kasturba Medical College, Mangalore, India
}

Submission Date: 21-5-2012; Accepted Date: 26-6-2012

\section{A BSTRACT}

The paper highlights the extent of the problem of anaemia, its associated causes along with the consequent effects on the overall health of the people as well as on the productivity of the nation. Different interventions implemented on country level scale as well as future lines of actions have been delineated. Anaemia is widely prevalent in India with over half of women and one-fourth of men suffer from anaemia. Anaemia directly causes 20 per cent of maternal deaths and indirectly accounts for another 20 per cent of maternal deaths. Nearly $79 \%$ of children aged 6-59 months are anemic. The estimated Disability Adjusted Life Years (DALYs) per 100,000 were 450 for the year 2004. A multi-intervention approach is needed encompassing adequate nutritional intake through dietary supplementation, food fortification and dietary modification, along with reduction of concurrent infection. There should be strengthening of Vitamin and Mineral Nutrition Information System (VMNIS) supported with firm political commitment.

Keywords: Anaemia, Burden, Prevention, India

\section{INTRODUCTION}

Anaemia is a condition in which the number of red blood cells or their oxygen-carrying capacity is insufficient to meet physiologic needs, which vary by age, sex, altitude, smoking and pregnancy status. The World Health Organization (WHO) definition of anaemia is a hemoglobin $(\mathrm{Hb})$ concentration $<130 \mathrm{~g} / \mathrm{L}$ in men, and $<120 \mathrm{~g} / \mathrm{L}$ in women. Further, WHO has proposed cut-off points for hemoglobin concentration below which anaemia should be considered to exist (Table 1). ${ }^{1}$

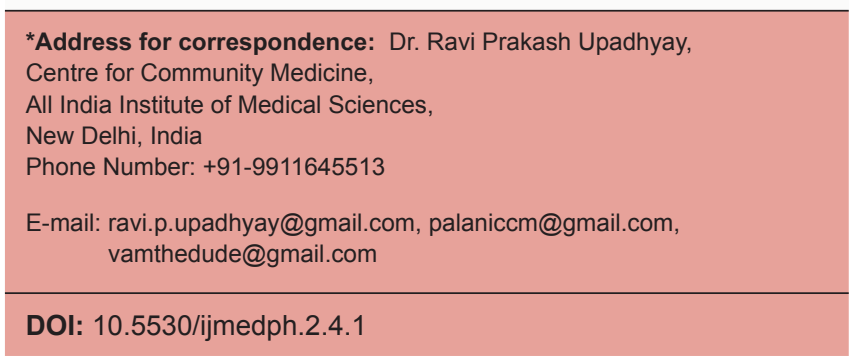

\begin{tabular}{lc} 
Table 1: Cut-off points for the diagnosis of anaemia \\
\hline $\begin{array}{c}\text { Hemoglobin } \\
\text { concentration in } \\
\text { venous blood }(\mathbf{g} / \mathbf{d l})\end{array}$ \\
\hline Adult males ( $\geq 15$ years) & 13 \\
Adult females, non-pregnant ( $\geq 15$ years) & 12 \\
Adult females, pregnant & 11 \\
Children aged (12.00-14.99 years) & 12 \\
Children aged (5.00-11.99 years) & 11.5 \\
Children aged (0.50-4.99 years) & 11 \\
\hline
\end{tabular}

\section{CAUSES OF ANAEMIA}

These can be broadly classified as:

1. Nutritional
A. Due to Iron deficiency
B. Due to Folic acid deficiency
C. Both Iron and Folic acid deficiency
2. Parasitic infestations like Hookworm and Malaria 
3. Chronic bacterial infections like chronic urinary tract infection, tuberculosis

4. Rare conditions like thalassemia minor, sickle cell anaemia

Iron deficiency anaemia is particularly common in tropics especially in women in the child bearing age group, more so in the under privileged sector. Low dietary intake of food rich in iron and folic acid is an important factor. High phosphate and phytic acid in Indian diet is one of the causes as they lead to formation of insoluble iron phosphate and phytates in the gut, thereby reducing iron absorption. Also, because of high prevalence of intestinal infestation, there is an increased intestinal hurry which reduces iron absorption.

In low and middle income countries, about 1.2 billion people are infected with roundworm and more than 700 million are infected with hookworm or whipworm. ${ }^{2}$ Infection with intestinal nematodes is linked with poverty because of its association with unsafe disposal of faeces, in which the infective stages develop. Malnutrition, which is quite rampant, is associated with hypochlorhydia which further hinders absorption. In females, repeated pregnancies at frequent intervals along with a prolonged period of lactation put a strain on the iron reserves. Excessive blood loss during menstruation which is usually left untreated and uncared for is another reason for iron deficiency anaemia among females. Presence of chronic infection interferes with erythropoiesis and may add to the problem.

Largely, there can be three concepts of disease causation. These include-Traditional biomedical concept according to which the disease (anaemia in present context) is caused due to presence of causative agents; Socio-epidemiological concept according to which the presence of mere causative agent doesn't ensure that the disease will occur. Social factors are important in disease causation and progression. Politico-developmental concept is a comprehensive approach and puts health in the context of various politicodevelopmental situations. According to this, government policies affect disease occurrence in some way or the other. Table 3 shows the application of these concepts in context of anaemia, in a developing nation like ours.

\begin{tabular}{|c|c|}
\hline \multicolumn{2}{|c|}{$\begin{array}{l}\text { Table 2: Classification of anaemia as a problem } \\
\text { of public health significance }\end{array}$} \\
\hline $\begin{array}{l}\text { Prevalence of anaemia } \\
(\%)\end{array}$ & $\begin{array}{l}\text { Category of public health } \\
\text { significance }\end{array}$ \\
\hline$\leq 4.9$ & No public health problem \\
\hline $5.0-19.9$ & Mild \\
\hline $20.0-39.9$ & Moderate \\
\hline$\geq 40.0$ & Severe \\
\hline
\end{tabular}

Table 3: Factors leading to anaemia grouped under the three concepts of disease causation

\begin{tabular}{|c|c|}
\hline $\begin{array}{l}\text { Traditional Bio-medical } \\
\text { concept }\end{array}$ & $\begin{array}{l}\text { Poor Iron Intake } \\
\text { Increased demand in pregnancy } \\
\text { Iron Malabsorption } \\
\text { Excess Iron Loss } \\
\text { Hookworm infestation } \\
\text { Malaria infection } \\
\text { Genetic disorders } \\
\text { Intestinal diseases }\end{array}$ \\
\hline $\begin{array}{l}\text { Socio-epidemiological } \\
\text { concept }\end{array}$ & $\begin{array}{l}\text { Factors included in traditional bio- } \\
\text { medical concept along with: } \\
\text { Wrong cultural beliefs/food taboos } \\
\text { Increased household work } \\
\text { Poverty and Illiteracy } \\
\text { Large Family size } \\
\text { Poor environmental conditions } \\
\text { No access to health facility }\end{array}$ \\
\hline $\begin{array}{l}\text { Politico-developmental } \\
\text { concept }\end{array}$ & $\begin{array}{l}\text { Besides the factors envisaged in } \\
\text { traditional bio-medical and Socio } \\
\text { epidemiological concept, it includes: } \\
\text { Lack of political commitment } \\
\text { Poor economic growth } \\
\text { Unsustainable development } \\
\text { Marginalization of lower socio-economic } \\
\text { strata }\end{array}$ \\
\hline
\end{tabular}

\section{BURDEN OF ANAEMIA IN INDIA}

Anaemia is widespread in every state. Over half of women and $24 \%$ of men suffer from anaemia and have lower than normal levels of blood hemoglobin. ${ }^{3}$ The prevalence is highest in all states in the East Region, especially Jharkhand and Bihar where more than twothirds of women and one-third of men are anemic. It is estimated that about $20 \%-40 \%$ of maternal deaths in India are due to anaemia. ${ }^{4}$ Anaemia has increased in evermarried women from $52 \%$ in NFHS- 2 to $56 \%$ in NFHS-3. Among pregnant women, anaemia has increased from $50 \%$ to $59 \% .^{5}$ As per NFHS-3 (2005-06), 79\% of children aged 6-59 months are anemic including 40\% who are moderately anemic and 3\% who are severely anemic. The only states in which less than half of children are anemic are Goa (38\%), Manipur (41\%), Mizoram (44\%) and Kerala (45\%).

The classification of countries can be done based on the prevalence of $\mathrm{Hb}$ values below the population-specific $\mathrm{Hb}$ threshold. Table 2 shows the classification of anaemia as a problem of public health significance. ${ }^{1}$ According to the WHO Global Database on Anaemia, for the year 1998-99/2000, the anaemia prevalence in India; in pre-school children, pregnant women and non-pregnant women in the reproductive age fell in the category of "severe" public health 
significance. ${ }^{6}$ As per the World Health Organization (WHO), Global Burden of Disease (2004) data, estimated total number of deaths per 1000 was 52.7. The estimated Disability Adjusted Life Years (DALYs) per 100,000 were 450 while the age-standardized DALYs per 100,000 were $445 .^{7}$

\section{IMPACT ON HEALTH AND PRODUCTIVITY}

Anaemia directly causes 20 per cent of maternal deaths in India and indirectly accounts for another 20 per cent of maternal deaths. ${ }^{4}$ Maternal morbidity rates are higher in women with $\mathrm{Hb}$ below $8 \mathrm{gm} / \mathrm{dl} .{ }^{8}$ Substantial proportion of maternal deaths due to ante partum and postpartum hemorrhage, pregnancy induced hypertension and sepsis occur in women with moderate anaemia. The other consequences include increased risk of abortions, low birth weight or prematurity, perinatal and neonatal mortality and inadequate iron stores for the newborn. Iron deficiency, the major cause of nutritional anemia impairs the fetal growth, cognitive development and immune system.

Iron deficiency may impair cellular responses and immune functions and consequently increase the susceptibility to infections. Moreover, the recovery from infections may be prolonged. Anemia is likely to adversely affect physical work capacity and cognition in young adolescent girls undergoing pubertal development. Anaemia, even when mild, causes a significant impairment of maximal work capacity. The more severe the anaemia, the greater is the reduction in work performance and thereby productivity which adversely affect the economy. The negative consequences of iron deficiency anaemia on cognitive and physical development of children, the building blocks of a nation, are of major concern.

Though sizeable literature on impact of micronutrient deficiencies on productivity exists at global level, the information at country level on this is scanty. In a study done by Administrative Staff College in 1997, three scenarios were taken to carry out the cost analysis of malnutrition. ${ }^{9}$ The three scenarios - low, moderate and high were based on the assumptions made on three indicators: productive life expectancy, average annual wage for an adult and average rate of employment were considered. The baseline values for the year 1997 are extrapolated to the year 2010 using the current inflation rates. In case of low scenario, the estimated annual productivity losses due to Iron deficiency came out to be Rs.305.8 billion while it turned out to be Rs. 750.0 billion in high scenario.

\section{DIFFICULTY OF ESTIMATING HEMOGLOBIN CONCENTRATION UNDER FIELD CONDITIONS}

Hemoglobin $(\mathrm{Hb})$ estimation is epochal for the detection of anaemia, for making crucial decisions regarding patient management and to monitor response to therapy. In resource strained conditions- high cost, inadequate training and lack of facilities are the hindering factors for the use of scientifically advanced equipments for anaemia screening. Clinical diagnosis is the most common method of detecting anaemia but this is unreliable and less useful for detecting mild anaemia. An ideal method in a resource strapped country like India should be cheap, reliable, durable, independent of power source, should not require large quantities of consumable reagents and should give immediate results. ${ }^{10}$ Methods for assessing hemoglobin levels by placing a drop of blood on a piece of blotting paper and then comparing against a color scale have been widely used in health centres in developing countries for the detection of anaemia.

In India, the most widely used quantitative methods are Sahli's method and Cynamethemoglobin methods. For use by the health workers at both the field and at the laboratory facility levels, Sahli's haemoglobinometer method of hemoglobin $(\mathrm{Hb})$ estimation has been recommended by the Government of India. Currently, the HemoCue method is extensively used for estimating the concentration of hemoglobin in capillary blood in field situations. HemoCue method was used for estimation of hemoglobin in nationwide National Family Health Surveys (NFHS)-II and III.

WHO devised a new color scale for the estimation of $\mathrm{Hb}$ levels which appears to meet the necessary criteria for use in wide-scale $\mathrm{Hb}$ estimation. The WHO hemoglobin color scale (HCS) is an easy and inexpensive method which measures hemoglobin between $4-14 \mathrm{~g} / \mathrm{dl}$ in $2 \mathrm{~g} / \mathrm{dl}$ increments. ${ }^{11}$ It provides a reliable indication of the presence and severity of anaemia where laboratory based methods are not available.

\section{INITIATIVES FOR ANAEMIA PREVENTION AND CONTROL IN INDIA}

\section{NATIONAL NUTRITIONAL ANEMIA PROPHYLAXIS} PROGRAMME: The programme was launched in 1970 to prevent nutritional anemia in mothers and children. Under this programme, expected and nursing mothers as well as acceptors of family planning are given one tablet of iron and folic acid containing $60 \mathrm{mg}$ elementary iron which is raised to $100 \mathrm{mg}$ elementary iron; however folic 
acid content remains the same (500 mcg of folic acid). ${ }^{12}$ Infant from the age of 6 months onwards up to the age of five years receive iron supplements in liquid formulation in doses of $20 \mathrm{mg}$ elemental iron and $100 \mathrm{mcg}$ folic acid per day for 100 days in a year. Children 6-10 years of age receive iron in the dosage of $30 \mathrm{mg}$ elemental iron and $250 \mathrm{mcg}$ folic acid for 100 days in a year and adolescents 11-18 years shall receive supplements at the same dosage as adults. ${ }^{13}$ This programme is being taken up by Maternal and Child Health $(\mathrm{MCH})$ Division of Ministry of Health and Family Welfare. Now it is part of RCH programme.

12 BY 12 INITIATIVE: A multi-pronged $12 \times 12$ initiative has been launched in the country for addressing the problem of anaemia. The target groups are the adolescents across the country. The aim is to achieve hemoglobin level of $12 \mathrm{gm} \%$ by the age of 12 years by 2012. ${ }^{14}$ The initiative comprises of health and nutrition education, weekly supplementation with iron folic acid tablet, parasite control through periodic de-worming, and appropriate immunization along with measures for capacity building. This initiative has been launched with the support of Government of India, Indian Council of Medical Research, World Health Organization, UNICEF, Federation of Obstetrics and Gynecological Societies of India and other professional bodies. ${ }^{15}$

ANEMIA CHALE JAO - NISCHAY - 2007: In the light of the fact that "illiteracy of health" of the women poses a hurdle towards detection and management of anaemia, it aimed to eliminate anaemia by 2007 by ensuring that every single Indian female must know her weight, height, blood group and hemoglobin level. The basis for this initiative was that $80 \%$ of females were not aware of their basic health parameters i.e. height, weight, $\mathrm{Hb} \%$ and blood group. ${ }^{16}$ Under this, women, once they had been diagnosed with suffering from anaemia, were given iron tablets for 1 month. This was started by Federation of Obstetrics \& Gynecological Society's of India (FOGSI).

FOOD FORTIFICATION: In 2004, Micronutrient Initiative (MI) supported the installation of a double fortified salt (DFS) manufacturing facility at the Tamil Nadu Salt Corporation (TNSC) plant, and currently provides 2 tons of iron premix every month as free subsidy to TNSC. ${ }^{17}$ In December 2007, MI and Global Alliance for Improved Nutrition (GAIN), in collaboration with the Flour Fortification Initiative (FFI) held a multi-stakeholder meeting in Delhi to review progress and lessons learned so far on wheat flour fortification and prepare a plan to accelerate the scaling up of this intervention. An "India Flour Fortification Network (IFFN)" was created at that meeting. ${ }^{18}$

Vita-Shakti and Anuka are the products developed by the MI in India to improve the intake of vitamins and minerals of young children. They are multiple micronutrient powder that is to be added to the food consumed by children 6-24 months of age. MI is currently testing the efficacy of Anuka in India and Indonesia. The feasibility and acceptability has been well proven in a few settings in India. ${ }^{19,20}$ MI developed lozenges fortified with vitamin $\mathrm{A}$, iron, and other nutrients, often called nutricandies or nutri-lozenges, to protect children who have no access to centrally processed and accessible foods to fortify. ${ }^{21}$ GAIN supports Naandi Foundation to supply fortified rice to school going children in the state of Andhra Pradesh as part of the Government of India's Midday Meal Scheme. ${ }^{22}$ The objective of the Midday Meal Scheme is to increase enrolment, retention and attendance while improving the nutritional status of students in primary classes.

Several other programmes focusing on issue of anemia include Integrated Child Development Services (ICDS), Mid-day meal programme, Kishori Swasthya Yojna, Matri Suraksha Abhiyan etc have been started. Most of these programmes have not had anticipated success reason being that majority of women present late in pregnancy with moderate or severe anemia, when little time is left to take corrective measures.

\section{KEY INTERVENTIONS REQUIRED}

\section{IMPROVING ANTENATAL SERVICES AND CREATING AWARENESS AMONG THE MOTHERS: Considering the huge} impact of anaemia on the health and productivity along with the fact that the "at risk" population i.e. pregnant and lactating women are not aware of their health needs and the ill effects of being anemic on their health and children emphasizes the need for increasing awareness and knowledge among them. ${ }^{23}$ Also needed is a cheap, durable and reliable method for anaemia screening through hemoglobin estimation. Strengthening of antenatal services, ensuring early detection of falling hemoglobin and its subsequent management through distribution of iron and folic acid tablets would be beneficial. Avoidance of frequent child birth through proper family planning guidance is a necessity. There is a growing need to focus on evidence based strategies aiming maternal and child health, adolescent health, safe motherhood, controlling 
malaria and deworming measures. For infants, exclusive breast feeding for six months, introduction of green leafy vegetables with cereal/pulse/oilseed mix in the seventh month for the prevention of anaemia will be useful and this could only be possible if the mothers are aware of these nutritional strategies.

ENSURING FOOD SECURITY: Iron deficiency in developing countries could probably be attributed to inadequate food intake as such and not because of reduced intake of iron rich food. India has the largest number of undernourished people in the world, 212 million - only marginally below the 215 million estimated for 1990-92. ${ }^{24}$ The Global Hunger Index (GHI) for India in the year 2010 is 24.1 which place it in the "alarming category" ${ }^{25}$ Keeping this in mind, there should be ways to ensure food security and amongst them the important ones could be measures to improve agricultural productivity and food storage, accurate targeting of below poverty line (BPL) candidates, introduction of innovative employment schemes, eliminating gender bias, ensuring women empowerment, crop diversification and establishing food grain banks.

\section{FOOD BASED APPROACH ALONG WITH FOOD}

FORTIFICATION: A multi-intervention approach is needed which should encompass adequate nutritional intake (through dietary supplementation, food fortification and dietary modification) along with reduction of concurrent infection, especially hookworm infestation. There should be focus on the food based approach rather than relying on iron tablets, syrups and other form of medical supplementations. Food based approaches, such as staple food fortification, consumption of food products and vegetables rich in iron, are likely to be more sustainable. The foods rich in iron are green vegetables, whole wheat, onion stalks, jaggery, egg, pulses etc and the point to stress here is that these food items are consumed normally as a part of the diet and thus, will not add any monetary burden on the people. Also, oral iron administration has its own share of side effects such as gastrointestinal irritation, epigastric discomfort, constipation, diarrhea and black stools. ${ }^{26}$ Food based approaches will be safer and devoid of such complications. Moreover, the cost of fortification per person per year comes in the range of $\$ 0.10$ (US) to $\$ 1.00$ which is quite less when compared to the expected benefits derived from fortification. ${ }^{27}$ "Sprinkles" could be an innovative approach to control iron deficiency and anemia in infants and children. This has been shown to be effective in the study done by Hirve $\mathrm{S}$. et al. where low dose sprinkles was as effective as iron drops in raising hemoglobin levels in anemic children. ${ }^{28}$
USING POSITIVE DEVIANCE APPROACH AS A TOOL: The implementation of positive deviance approach has the potential to yield good results as documented by studies. A study by Ndiaye M. et al. which compared positive deviance approach with an ongoing integrated nutrition and health program intervention (Micah) in a rural Senegalese area found that a community-based strategy, such as the positive deviance approach, could contribute to improving the effectiveness of iron supplementation during pregnancy. ${ }^{29}$ In India, some interventions used the "positive deviance approach" (e.g., the Adolescent Anemia Control Program for Girls in Vadodara District and the UMANG Project in Uttar Pradesh) with significant results and this approach should be further implemented and documented. ${ }^{30}$

STRENGTHENING THE SURVEILLANCE SYSTEM: There should be a system of quality assurance both internal and external in place. There should be a better surveillance system for vitamin and micronutrient deficiencies with the aim to retrieve and summarize data on vitamin and mineral status of the population and track the progress made. The data provided from national level periodic surveys like National Family Health Survey should not be entirely relied upon. Instead, there should be strengthening of Vitamin and Mineral Nutrition Information System (VMNIS). VMNIS was originally established in 1991 by the Nutrition Unit of the World Health Organization in collaboration with the Department of International Health of the University of Michigan, United States of America.

Though a number of nutrition based initiatives have been initiated in the country but to be effective and sustainable, these must backed by firm political commitment and partnerships involving all relevant sectors. Efforts should be made by the concerned health departments and authorities to execute and supervise the functioning of the nutrition related schemes in an efficient way. The need of the hour is to accept the challenge and catalyze the necessary actions.

Ethical Approval: Not required

Funding: None declared

Competing interests: None declared

\section{REFERENCES}

1. World Health Organization (2001). Iron deficiency anaemia: assessment, prevention, and control. A guide for programme managers. Geneva: (WHO/NHD/01.3). 
2. De Silva NR, Brooker S, Hotez PJ, Montresor A, Engels D, Savioli L. Soil-transmitted helminths: updating the global picture. Trends Parasitol 2003;19:547-51.

3. IIPS and Macro International. National Family Health Survey (NFHS-3), 2005-06: India. International Institute for Population Sciences: Mumbai, 2007.

4. Maternal Mortality in India 1997-2003, Registrar General of India. Retrieved from: http://www.censusindia.net/, accessed on 5.03.2012.

5. IIPS and ORC Macro. National Family Health Survey (NFHS- 2), 1998-99: India. International Institute for Population Sciences: Mumbai, 2000.

6. de Benoist B, McLean E, Egli I, Cogswell M. Worldwide prevalence of anaemia 1993-2005. WHO Global Database on Anaemia (2008), pp.21-31.

7. http://www.who.int/healthinfo/global_burden_disease/gbddeathdalycountryestimates2004.xls, accessed on 10.03.12.

8. Kalaivani K. Prevalence \& consequences of anaemia in pregnancy. Indian J Med Res 2009;130:627-33.

9. National Strategy to reduce childhood malnutrition: Final report; Ministry of Human Resource Development: Government of India, Administrative staff college of India, Hyderabad. December 1997.

10. Munster M, Lewis SM, Erasmus LK, Mendelow BV. Field evaluation of a novel haemoglobin measuring device designed for use in a rural setting. S Afr Med J 1997;87:1522-6.

11. Ingram CF, Lewis SM. Clinical use of WHO hemoglobin colour scale: Validation and critique. J Clin Pathol 2000;53:933-7.

12. National Nutrition Policy. Government of India. Department of Women \& Child Development, Ministry of Human Resource Development, New Delhi 1993. p.14; Retrieved from: http://wcd.nic.in/nnp.pdf, accessed from 11.03.2012.

13. Annual Report 2008-09. Ministry of Health and Family Welfare, Government of India. p.73.

14. http://www.whoindia.org/en/Section6/Section324_1467.htm, accessed on 13.03.2012.

15. http://www.12by12initiative.com/iis.asp, accessed on 13.03.2012.

16. http://nischay2007.tripod.com/id2.html, accessed on 16.03.2012.

17. Controlling vitamin \& mineral deficiencies in India: Meeting the goal. The Micronutrient Initiative. p.17; Retrieved from: http://www.micronutrient.org/ resources/publications/Controlling\%20VMD\%20India.pdf, accessed on 27.03.2012.

18. http://www.micronutrient.org/English/view.asp? $x=603$, accessed on 27.03.2012
19. MI Toolkit Products for Emergencies and Food Security Programs. The Micronutrient Initiative. http://www.micronutrient.org/CMFiles/What $\% 20$ we $\% 20$ do/New\%20Solutions $\% 20$-\%20Emergencies/VitaShakti.pdf, accessed on 07.04.2012.

20. MI Toolkit Products for Emergencies and Food Security Programs. The Micronutrient Initiative. http://www.micronutrient.org/CMFiles/What $\% 20$ we\%20do/New\%20Solutions\%20-\%20Emergencies/Anuka.pdf, accessed on 07.04 .2012

21. Micronutrient Initiative. Solutions for hidden hunger. Annual report 200607. p. 7.

22. Documentation of Best Practice. Naandi Foundation: The Midday Meal Programme; September 2010. p. 6.

23. Bentley $P$, Parekh A. Perceptions of anaemia and health seeking behavior among women in four India states. Technical working paper 9. Mother Care/John Snow, Inc. October 1998. pp. 6-7. http://pdf.usaid.gov/pdf_ docs/Pnack491.pdf, accessed on 11.04.2012.

24. The state of food insecurity in the world 2006. Eradicating world hungertaking stock ten years after the World Food Summit. FAO corporate documentry repository. p.14.

25. Grebmer KV, Ruel MT, Menon P, Nestorova B, Olofinbiyi T, Fritschel H, Yohannes Y, Oppeln CV, Towey O, Golden K, Thompson J (2010). Global Hunger Index - The challenge of hunger: focus on the crisis of child under nutrition. Bonn, Washington D. C., Dublin. p.17.

26. http://my.clevelandclinic.org/disorders/anemia/hic_oral_iron supplementation.aspx, accessed on 12.04.2012.

27. Badham J, Zimmermann MB, Kraemer K (2007). Nutritional Anaemia Guidebook. Sight and Life Press. p.15. http://www.sightandlife.org/pdf/ NAguidebook.pdf, accessed on 23.04.2012.

28. Hirve S, Bhave S, Bavdekar A, Naik S, Pandit A, Schauer C, Christofides A, Hyder Z, Zlotkin S. Low dose 'Sprinkles' - An innovative Approach to Treat Iron Deficiency Anemia in Infants and Young Children. Indian Pediatr 2007;44:91-100.

29. Ndiaye M, Siekmans K, Haddad S, Receveur O. Impact of a positive deviance approach to improve the effectiveness of an iron-supplementation program to control nutritional anemia among rural Senegalese pregnant women. Food Nutr Bull 2009;30(2):128-36.

30. Community-level interventions to prevent and treat anemia: A review of evidence from India. Evidence review series 2008. p. 3. 